\title{
PENGETAHUAN DAN EFIKASI DIRI MAHASISWA KESEHATAN DALAM PERILAKU PENCEGAHAN PENULARAN COVID-19
}

\author{
Kartini $^{1)}$, Hera Hastuti ${ }^{2)}$, Annisaa Fitrah Umara ${ }^{3)}$, Shieva Nur Azizah ${ }^{4)}$, Rizkiyani Istifada ${ }^{5)}$ \\ Eriyono Budi Wijoyo ${ }^{6}$ \\ ${ }_{1,4}$ Program Studi Sarjana Keperawatan, Fakultas Ilmu Kesehatan, Universitas Muhammadiyah Tangerang, \\ Kota Tangerang, Banten, Indonesia \\ 2,3,5,6 Program Studi Profesi Ners, Fakultas Ilmu Kesehatan, Universitas Muhammadiyah Tangerang, \\ Kota Tangerang, Banten, Indonesia \\ email: kartinich@gmail.com
}

\begin{abstract}
Abstrak
Mahasiswa merupakan kelompok yang memiliki mobilitas tinggi dalam aktivitas di luar rumah. Berbagai faktor mempengaruhi perilaku mahasiswa, salah satunya pengetahuan dan efikasi diri. Tujuan penelitian ini untuk mendeskripsikan hubungan pengetahuan dan efikasi diri mahasiswa dalam perilaku pencegahan penularan COVID-19 setelah satu tahun pandemi. Metode penelitian menggunakan studi kuantitatif dengan desain cross-sectional. Penelitian ini telah lolos uji etik dengan jumlah responden yang terlibat adalah 228 mahasiswa. Analisis data menggunakan tes chi-square. Hasil penelitian menunjukkan adanya hubungan pengetahuan dan efikasi diri dengan perilaku mahasiswa dalam pencegahan penularan COVID-19 setelah satu tahun pandemi ( $p$-value <0,05). Akses informasi yang mudah didapat oleh mahasiswa berdampak pada peningkatan pengetahuan dan nilai efikasi diri. Oleh karena itu dibutuhkan dukungan dari berbagai lintas sektoral dan keluarga untuk mempertahankan pengetahuan dan motivasi positif mahasiswa dalam perilaku pencegahan COVID-19.
\end{abstract}

Kata kunci: COVID-19, efikasi diri, mahasiswa, pengetahuan, perilaku

\begin{abstract}
College students are a group that has high mobilization activity outside. Various factors influence college student behavior, one of which is knowledge and self-efficacy. The aim of this study was to describe the relationship between knowledge and self-efficacy of college students in preventing COVID-19 transmission behavior after one year of the pandemic. The research method used a quantitative study with a crosssectional design. This research had passed the ethical test with the number of respondents involved are 228 college students. Data analysis used a chi-square test. The results showed a relationship between knowledge and self-efficacy with college student behavior in preventing COVID-19 transmission after one year of the pandemic ( $p$-value <0,05). The information that is accessible for students has an impact on increasing knowledge and self-efficacy values. Therefore, it takes support from various sectoral and families to maintain positive knowledge and motivation of students in COVID-19 prevention behavior.
\end{abstract}

Keywords: COVID-19, self-efficacy, college students, knowledge, behavior

\section{PENDAHULUAN}

Pandemi COVID-19 menimbulkan ketakutan pada masyarakat di berbagai belahan dunia. Sudah lebih dari satu tahun semenjak pandemi bergulir sampai dengan sekarang belum ada tanda-tanda kasus akan turun. Bahkan dalam satu tahun ini ada peningkatan jumlah terkonfirmasi dan terjadi mutasi dari virus Corona (Parwanto, 2021). Adanya mutasi menyebabkan penyebaran virus Corona semakin cepat.

Penyebaran COVID-19 dari manusia ke manusia membuat penyebaran menjadi sangat agresif sehingga perlu adanya upaya pencegahan (Moudy \& Syakurah, 2020; Susilo et al., 2020). Salah satu upaya Pemerintah Indonesia saat ini yaitu melalui penerapan physical distancing, pembatasan gerak, penggunaan masker, melakukan karantina terhadap penderita yang mengalami gejala mirip COVID-19 dan 
penerapan pembatasan mobilitas berskala besar serta menerapkan pola hidup bersih dan sehat (Yunus \& Rezki, 2020). Hal tersebut dilakukan guna menekan jumlah kasus dan penyebaran COVID-19 (Kementerian Kesehatan Republik Indonesia, 2020). Pencegahan penularan COVID-19 ini dapat dilakukan oleh semua kalangan masyarakat khususnya mahasiswa.

Mahasiswa merupakan kelompok masyarakat yang cenderung aktif beraktivitas di luar rumah, memiliki status imunitas yang baik, pada umumnya tidak memiliki penyakit penyerta, meskipun demikian tetap berpeluang mengidap COVID-19 karena tinggi aktivitas di luar rumah (Mona, 2020; Zhong et al., 2020). Mahasiswa kesehatan memiliki pengetahuan dan efikasi diri yang positif terkait kesehatan masyarakat (Murhadi \& Kurniawati, 2019; Setyaningrum, 2019). Salah satunya terkait dengan pencegahan penularan COVID-19.

Pengetahuan mahasiswa kesehatan terkait dengan COVID-19 sangat baik karena mereka mempelajari terkait dengan proses awal mula virus COVID-19 sampai dengan penularannya dari manusia ke manusia (Peng et al., 2020; Susanti \& Sri, 2020). Pengetahuan yang baik dapat meningkatkan efikasi diri pada mahasiswa sehingga dapat mengubah perilaku menjadi baik terutama pencegahan penularan COVID-19. Penelitian Baringbing \& Purba (2020) menyatakan bahwa ada hubungan yang lemah antara efikasi diri dengan perubahan perilaku pencegahan COVID-19. Hal ini menandakan bahwa ada banyak faktor yang mempengaruhi perubahan perilaku sehingga peneliti akan memperdalam hal tersebut. Penelitian ini menjadi penting untuk dasar penelitian selanjutnya terkait dengan faktor-faktor yang menyebabkan perubahan perilaku seseorang.

Tujuan penelitian ini adalah mempelajari hubungan antara pengetahuan dan efikasi diri mahasiswa dengan perilaku dalam pencegahan penularan COVID-19 dalam satu tahun setelah pandemi.

\section{METODE PENELITIAN}

Penelitian ini merupakan penelitian kuantitatif dengan pendekatan metode crosssectional. Teknik pengumpulan sample dalam penelitian ini yaitu purposive sampling dengan menggunakan kuisioner pengetahuan, efikasi diri dan perilaku. Dalam penelitian ini menggunakan uji Analisis bivariat yaitu uji chi-square. Jumlah responden dalam penelitian ini 228 orang yang merupakan mahasiswa kesehatan (Keperawatan dan Kebidanan) Universitas Muhammadiyah Tangerang. Penelitian ini dilakukan pada bulan April-Mei 2021. Etika penelitian sudah mendapatkan persetujuan etik dengan nomor 060/PE/KE/FKK-UMJ/II/2021.

\section{HASIL DAN PEMBAHASAN}

\section{a. Karakteristik Responden}

Tabel 1. Karakteristik Demografi Responden $(n=228)$

\begin{tabular}{|c|c|c|}
\hline Variabel & Jumlah & $\begin{array}{c}\text { Persentase } \\
(\%)\end{array}$ \\
\hline Jenis Kelamin & & \\
\hline Laki-laki & 14 & 6,1 \\
\hline Perempuan & 214 & 93,9 \\
\hline Mahasiswa & & \\
\hline Keperawatan & 161 & 70,6 \\
\hline Kebidanan & 67 & 29,4 \\
\hline Terkonfirmasi & & \\
\hline COVID-19 & & \\
\hline $\mathrm{Ya}$ & 15 & 6,6 \\
\hline Tidak & 213 & 93,4 \\
\hline Keluarga & & \\
\hline Terkonfirmasi & & \\
\hline COVID-19 & & \\
\hline $\mathrm{Ya}$ & 18 & 7,9 \\
\hline Tidak & 210 & 92,1 \\
\hline $\begin{array}{l}\text { Jumlah anggota } \\
\text { keluarga yang } \\
\text { terkonfirmasi COVID- } \\
19\end{array}$ & & \\
\hline 1 orang & 104 & 45,6 \\
\hline 2 orang & 67 & 29,4 \\
\hline 3 orang & 28 & 12,3 \\
\hline$\geq 4$ orang & 29 & 12,7 \\
\hline Total & 228 & 100 \\
\hline
\end{tabular}

Karakteristik responden pada penelitian ini terdiri dari jenis kelamin, program studi mahasiswa, pengalaman mahasiswa dan keluarga terkonfirmasi COVID-19, serta jumlah anggota keluarga mahasiswa yang terkonfirmasi COVID19. Sebagian besar responden yang terlibat dalam penelitian ini berjenis kelamin perempuan (93,9\%), Sebagian merupakan mahasiswa program studi keperawatan $(70,6 \%)$. Sebagian besar mahasiswa mengakui tidak pernah terkonfirmasi COVID-19 (93,4\%) dan hanya 7,9\% keluarga mahasiswa yang pernah terkonfirmasi COVID-19. Berdasarkan angket yang disebar kepada mahasiswa menjelaskan hanya ada 1 anggota keluarga mereka yang terkonfirmasi COVID-19, walaupun sebesar $12,7 \%$ mendeskripsikan $\geq 4$ anggota keluarga juga terkonfirmasi (Tabel 1). 
b. Gambaran Pengetahuan, Efikasi Diri, dan Perilaku Mahasiswa dalam Perilaku Pencegahan Penularan COVID-19 setelah Satu Tahun Pandemi

Tabel 2. Pengetahuan dan Efikasi Diri Mahasiswa dalam Perilaku Pencegahan Penularan COVID-19

\begin{tabular}{ccc}
\hline Variabel & Jumlah & $\begin{array}{c}\text { Persentase } \\
(\%)\end{array}$ \\
\hline $\begin{array}{c}\text { Pengetahuan } \\
\text { Tinggi }\end{array}$ & 114 & 50 \\
Rendah & 114 & 50 \\
Efikasi Diri & & \\
Positif & 137 & 60,1 \\
Negatif & 91 & 39,9 \\
Perilaku & & \\
Baik & 129 & 56,6 \\
Kurang Baik & 99 & 43,4 \\
\hline Total & 228 & 100 \\
\hline
\end{tabular}

Hasil penelitian ini memiliki keunikan terhadap persentase variabel pengetahuan tinggi dan pengetahuan rendah yang menunjukkan nilai sama besar (Tabel 2). Sebagian besar mahasiswa telah mengetahui tanda dan gejala, perbedaan dengan flu biasa, serta risiko tertular COVID-19 pada seseorang komorbid. Namun, sebesar 38,6\% responden masih menjawab kurang tepat pada salah satu cara penularan COVID-19 akibat dari hewan liar. Sebagian besar responden memiliki efikasi diri yang positif $(60,1 \%)$. Namun, beberapa responden $(25,8 \%)$ menyatakan masih belum dapat mengandalkan kemampuan yang dimiliki saat menghadapi dirinya/keluarga terinfeksi COVID-19. Hasil penelitian ini juga menunjukkan 56,6\% responden memiliki perilaku baik. Namun, sebagian responden mengakui jarang mengonsumsi suplemen herbal $(61,8 \%)$, jarang melakukan latihan fisik secara teratur $(39,9 \%)$, dan jarang melakukan diet sehat secara rutin $(57,5 \%)$.

\section{c. Analisis Hubungan Pengetahuan dengan Perilaku Mahasiswa dalam Pencegahan Penularan COVID-19}

Berdasarkan hasil analisis bivariat (Tabel 3) menunjukkan adanya hubungan pengetahuan dengan perilaku mahasiswa setelah satu tahun pandemi ( $p 0,007<0,05$ ). Mahasiswa dengan pengetahuan rendah memiliki resiko untuk berperilaku kurang baik sebanyak 1,39 kali dibandingkan mahasiswa dengan pengetahuan tinggi. Hasil penelitian ini juga menunjukkan sebanyak sebagian besar mahasiswa pengetahuan tinggi memiliki perilaku baik, sedangkan sebagian besar mahasiswa dengan pengetahuan rendah memiliki perilaku kurang baik.

Penelitian ini sejalan dengan penelitian Susanti \& Sri (2020) yang menunjukkan pengetahuan bahwa mahasiswa dengan kategori tinggi tentang COVID-19 yaitu $42.5 \%$ dan rendah sebesar $57.5 \%$. Hasil penelitian ini didukung oleh penelitian Peng et al. (2020) yang menyatakan bahwa pengetahuan mahasiswa Cina terkait dengan COVID-19 dengan hasil pengetahuan baik sebesar 82,3\%. Selain itu, penelitian di Wonosobo menunjukkan adanya hubungan antara pengetahuan dengan perilaku masyarakat tentang COVID-19 dengan p value $=0,047$ (Purnamasari \& Raharyani, 2020).

Tabel 3. Analisis Hubungan Pengetahuan Mahasiswa dalam Perilaku Pencegahan Penularan COVID-19

\begin{tabular}{|c|c|c|c|c|c|c|c|c|}
\hline \multirow{3}{*}{ Pengetahuan } & \multicolumn{4}{|c|}{ Perilaku } & \multirow{2}{*}{\multicolumn{2}{|c|}{ Total }} & \multirow{3}{*}{ PR CI 95\% } & \multirow{3}{*}{$\begin{array}{c}P \\
\text { value }\end{array}$} \\
\hline & \multicolumn{2}{|c|}{ Baik } & \multicolumn{2}{|c|}{ Kurang Baik } & & & & \\
\hline & $\mathbf{n}$ & $\%$ & $\mathbf{N}$ & $\%$ & $\mathbf{N}$ & $\%$ & & \\
\hline Tinggi & 75 & 65,8 & 39 & 34,2 & 114 & 100 & \multirow{3}{*}{$\begin{array}{c}1,39 \\
(1,30-1,49)\end{array}$} & \multirow{3}{*}{0,007} \\
\hline Rendah & 54 & 47,4 & 60 & 52,6 & 114 & 100 & & \\
\hline Jumlah & 129 & 56,6 & 99 & 43,4 & 228 & 100 & & \\
\hline
\end{tabular}

Tabel 4. Analisis Hubungan Efikasi Diri dengan Perilaku Mahasiswa dalam Pencegahan COVID-19

\begin{tabular}{|c|c|c|c|c|c|c|c|c|}
\hline \multirow{3}{*}{ Efikasi Diri } & \multicolumn{4}{|c|}{ Perilaku } & \multirow{2}{*}{\multicolumn{2}{|c|}{ Total }} & \multirow{3}{*}{ PR CI 95\% } & \multirow{3}{*}{ P value } \\
\hline & \multicolumn{2}{|c|}{ Baik } & \multicolumn{2}{|c|}{ Kurang Baik } & & & & \\
\hline & $\mathrm{n}$ & $\%$ & $\mathbf{n}$ & $\%$ & $\mathbf{N}$ & $\%$ & & \\
\hline Positif & 97 & 70,8 & 40 & 29,2 & 137 & 100 & \multirow{3}{*}{$\begin{array}{c}1,4 \\
(1,31-1,50)\end{array}$} & \multirow{3}{*}{0,000} \\
\hline Negatif & 32 & 35,2 & 59 & 64,8 & 91 & 100 & & \\
\hline Jumlah & 129 & 56,6 & 99 & 43,4 & 228 & 100 & & \\
\hline
\end{tabular}


Hasil penelitian ini berbeda dengan penelitian sebelumnya yang dilakukan oleh Baloran (2020), bahwa siswa di Filipina memiliki cukup pengetahuan tentang pencegahan COVID19. Selain itu penelitian lain juga sependapat bahwa pengetahuan mahasiswa sebagian besar buruk di salah satu universitas di Bangladesh (Wadood et al., 2020). Penyebab pengetahuan yang buruk dikarenakan keterbatasan akses informasi, masih ada sebagian penduduk yang buta huruf, banyaknya lansia di pedesaan akan lebih berisiko memiliki pengetahuan yang buruk dalam pencegahan COVID-19 (Salman et al., 2020). Salah satu penyebab pengetahuan kurang yang bisa dialami oleh mahasiswa yaitu karena keterbatasan akses yang dimiliki oleh mahasiswa terutama dalam penelitian ini.

Pengetahuan adalah suatu hasil dari rasa ingin tahu melalui proses sensoris, terutama pada mata dan telinga terhadap objek tertentu (Donsu, 2019). Pengetahuan yang dimiliki seseorang sebagian besar berasal dari proses pendidikan baik itu pendidikan formal maupun informal. Proses pengetahuan seseorang bersumber dari pengalaman pribadi maupun pengalaman orang lain yang kemudian dipelajari. Selain itu pengetahuan juga bersumber dari media massa serta hasil interaksi dengan lingkungan (Siltrakool, 2017). Seseorang yang telah mengetahui tentang suatu informasi tertentu, maka dia akan mampu menentukan dan mengambil keputusan bagaimana dia harus menghadapinya. Dengan kata lain, saat seseorang mempunyai informasi tentang COVID-19, maka ia akan mampu untuk menentukan bagaimana dirinya harus berperilaku terhadap COVID-19 tersebut (Yulianti, 2021). Sehingga apabila seseorang mengetahui pencegahan penularan COVID-19 maka mereka akan melakukan perilaku yang baik pula.

Pengetahuan merupakan domain terpenting dalam terbentuknya perilaku (Donsu, 2019) Perilaku adalah respons yang dapat diamati baik yang disadari maupun yang tidak disadari dari seseorang terhadap stimulus yang berasal dari dalam dan luar individu (Taye et al., 2020). Seseorang yang mempunyai pengetahuan yang baik terkait perilaku sehat maka ada kecenderungan untuk berperilaku yang baik pula. Hal ini berarti bahwa untuk meningkatkan perilaku sehat dan selamat, maka perlu juga meningkatkan pengetahuan mengenai kesehatan (Apriluana et al., 2016). Sehingga dapat disimpulkan bahwa semakin seseorang mengetahui akan hal baik seperti pada pengetahuan dan perilaku pencegahan penularan
COVID-19 maka akan berdampak pada perilakunya untuk melakukan pencegahan tersebut.

Pengetahuan memegang peranan penting dalam menentukan perilaku yang utuh karena pengetahuan akan membentuk kepercayaan yang selanjutnya dalam mempersepsikan kenyataan, memberikan dasar bagi pengambilan keputusan dan menentukan perilaku terhadap objek tertentu sehingga akan mempengaruhi seseorang dalam berperilaku (Novita \& Yuliastuti, 2014). Pengetahuan yang baik tentang bahaya penyakit tertentu, memicu individu untuk berperilaku pencegahan baik (Timah, 2021). Pengetahuan yang baik dapat didukung oleh penerimaan terhadap informasi yang beredar di masyarakat tentang COVID-19 (Zulva, 2020). Penerimaan terhadap perilaku baru akan lebih langgeng bila didasarkan oleh pengetahuan, sedangkan perilaku tersebut tidak akan bertahan lama tanpa didasarkan oleh pengetahuan (Silalahi et al., 2013). Pengetahuan yang baik akan menjadi dasar yang kuat untuk merubah perilaku terutama pencegahan penularan COVID-19.

Mahasiswa kesehatan sebagai diri pribadi dengan kehidupan yang mereka jalani memiliki dampak risiko kesehatan yang tinggi, maka menjadi penting bagi mereka untuk meningkatkan kesadaran diri akan informasi kesehatan bagi dirinya. Isu-isu kesehatan, masalah kesehatan serta solusi kesehatan yang terbaik bagi mereka perlu dipahami dan dipergunakan sebagai informasi kesehatan untuk meningkatkan dan mempertahankan kesehatan mereka (Hakiman et al., 2016). Mahasiswa kesehatan menjadi role model yang baik dan berpengaruh bagi masyarakat untuk berperilaku baik dalan pencegahan penularan COVID-19.

\section{d. Analisis Hubungan Efikasi Diri dengan Perilaku Mahasiswa dalam Pencegahan Penularan COVID-19}

Hasil penelitian ini menunjukkan adanya hubungan antara efikasi diri dengan perilaku mahasiswa dalam pencegahan COVID-19 setelah satu tahun pandemi $(\mathrm{p}=0,000<0.005)$. Berdasarkan uji analisis bivariat (Tabel 4) menunjukkan sebagian besar mahasiswa dengan efikasi diri positif memiliki perilaku baik. Sebaliknya, sebagian besar mahasiswa dengan efikasi diri negatif memiliki perilaku kurang baik. Responden dengan efikasi diri negatif berpeluang memiliki perilaku kurang baik sebesar 1,4 kali dibandingkan responden dengan efikasi diri positif. 
Hasil penelitian ini sejalan dengan penelitian Baringbing \& Purba (2020) yang menyatakan terdapat hubungan positif antara efikasi diri dengan perilaku pencegahan pada masyarakat. Artinya semakin tinggi efikasi diri seseorang, maka semakin tinggi pula perilaku pencegahan COVID-19. Kemampuan efikasi diri dalam memprediksi perilaku pencegahan COVID-19 sangatlah kecil, hanya $7 \%$ maka diperlukan intervensi atau promosi perilaku pencegahan COVID-19 berbasis peningkatan efikasi diri. Perilaku yang baik seringkali diperlihatkan masyarakat dengan berusaha mencegah dan memutuskan rantai penyebaran COVID-19 sesuai dengan protokol kesehatan.

Mahasiswa kesehatan seperti mahasiswa kebidanan dan keperawatan di tengah pandemi wabah COVID-19 dihadapkan pada berbagai tantangan dalam melakukan aktivitas sehingga memerlukan strategi yang tepat untuk tetap menjaga perilaku sehat (Setyaningrum, 2019). Salah satu cara yang bisa dilakukan yaitu dengan meningkatkan efikasi diri. Keyakinan yang tertanam pada diri indivdu akan mempengaruhi kelangsungan perilaku individu itu sendiri. Efikasi diri merupakan penentu utama berlangsungnya suatu perilaku. Efikasi diri yang positif di dalam diri individu cenderung membuat dirinya akan tetap berkonsentrasi penuh untuk menjalankan tugas-tugasnya sesuai dengan kemampuan diri dan cenderung mempunyai sikap percaya bahwa dirinya mampu untuk menyelesaikan semua tugasnya (Bandura, 2013). Individu yang berhasil membangun keyakinannya akan memiliki efikasi diri yang positif serta akan melakukan lebih dari sekedar menyampaikan penilaian positif (Ahmad, 2013). Jadi dapat disimpulkan mahasiswa kesehatan diharapkan dapat memiliki efikasi diri yang positif agar perilaku dalam pencegahan penularan COVID-19 dapat dilakukan dengan baik.

Seseorang dengan efikasi diri yang positif mempunyai pandangan untuk sukses dan yakin akan kemampuan yang dimiliki (Shofiah \& Raudatussalamah, 2014). Pikiran positif akan membangun kepercayaan diri dan mempermudah pencapaian tujuan. Keyakinan ini juga memicu motivasi untuk berusaha dalam menyelesaikan berbagai tugas yang ada (Safitri \& Masykur, 2017). Seseorang dengan efikasi diri yang positif akan mempunyai semangat untuk melanjutkan tulisannya meskipun dihadapkan pada berbagai tantangan, serta mempunyai keinginan yang tinggi untuk mencapai tujuan atau target yang telah ditetapkan (ALBaddareen et al., 2015). Mahasiswa kesehatan diharapkan dapat menjadi seseorang dengan efikasi tinggi karena mendapatkan ilmu yang sesuai untuk menyelesaikan persoalan salah satunya meningkatkan perilaku pencegahan penularan COVID-19.

Individu yang tidak menganggap diri mereka kompeten kehilangan motivasi untuk menyelesaikan tugas-tugas sulit dan fokus pada kemungkinan kegagalan yang dapat terjadi (AL-Baddareen et al., 2015). Salah satu alasannya adalah karena pandangan negatif pada kemampuan diri sendiri. Seseorang dengan efikasi diri negatif juga tidak mencari peluang untuk memperoleh pengetahuan atau keterampilan yang diperlukan untuk menciptakan keberhasilan, termasuk membangun kepercayaan diri pada kemampuannya (Rustika, 2016). Mahasiswa kesehatan terutama kebidanan dan keperawatan diharapkan dapat menghilangkan pikiran negatif tentang diri sendiri agar meningkatkan efikasi diri atau keyakinan pada dirinya sendiri.

\section{KESIMPULAN DAN SARAN}

Setelah satu tahun pandemi, sebagian besar mahasiswa kesehatan memiliki pengetahuan tinggi, efikasi diri positifdan perilaku yang baik dalam pencegahan penularan COVID-19. Ada hubungan pengetahuan dan efikasi diri dengan perilaku mahasiswa kesehatan dalam pencegahan penularan COVID-19. Adanya kemudahan untuk mendapatkan akses informasi menjadi salah satu faktor bagi mahasiswa kesehatan untuk melakukan pencegahan penularan COVID-19.

Tingginya aktivitas yang dilakukan menjadi rentan bagi keluarga yang hidup bersama mahasiswa. Oleh karena itu, dibutuhkan peran dan kerja sama yang baik antara pihak perguruan tinggi, pemegang kebijakan, dan keluarga dalam menjaga komitmen mahasiswa sebagai role model bagi masyarakat untuk memiliki perilaku pencegahan COVID-19 yang baik. Saran terkait penelitian perlu dilakukan analisis faktor-faktor yang mempengaruhi perilaku pencegahan COVID-19 dikarenakan efikasi diri hanya memiliki kemampuan yang kecil dalam memprediksi perilaku seseorang.

\section{REFERENSI}

Ahmad, A. (2013). Effects of Self-Efficacy on Students' Academic Performance. Journal of Educational, Health and Community Psychology, 2(1), 22-29. https://doi.org/10.12928/jehcp.v2i1.3740

AL-Baddareen, G., Ghaith, S., \& Akour, M. (2015). Self-Efficacy, Achievement Goals, and Metacognition as Predicators of Academic Motivation. Procedia - Social and Behavioral Sciences, 191, 2068-2073. https://doi.org/10.1016/j.sbspro.2015.04.345 
Apriluana, G., Khairiyati, L., \& Setyaningrum, R. (2016). Hubungan Antara Usia, Jenis Kelamin, Lama Kerja, Pengetahuan, Sikap Dan Ketersediaan Alat Pelindung Diri (APD) Dengan Perilaku Penggunaan Apd Pada Tenaga Kesehatan. Jurnal Publikasi Kesehatan Masyarakat Indonesia, 3(3), 8287.https://doi.org/10.20527/jpkmi.v3i3.2754

Baloran, E. T. (2020). Knowledge, Attitudes, Anxiety, and Coping Strategies of Students during COVID19 Pandemic. Journal of Loss and Trauma, 25(8), 635-642. https://doi.org/10.1080/15325024.2020. 1769300

Bandura, A. (2013). Self-efficacy and social cognitive theories. PennState.

Baringbing, N., \& Purba, R. M. (2020). Self-Efficacy and COVID-19 Preventive Behaviors. Jurnal Pemikiran Dan Penelitian Psikologi, 15(2), 6871.https://doi.org/10.32734/psikologia.v15i2.49 07

Donsu, J. D. T. (2019). Psikologi Keperawatan. Rineka Cipta.

Hakiman, A. P., Dewi, S. P., Sayusman, C., \& Wahyudi, K. (2016). Persepsi Mahasiswa Profesi Kesehatan Universitas Padjadjaran Terhadap Interprofessionalism Education. Jurnal Sistem Kesehatan, 1(4), 206-213. https://doi.org/10.24198/jsk.v1i4.10382

Kementerian Kesehatan Republik Indonesia. (2020). Apa Yang Harus Dilakukan Masyarakat Untuk Cegah Penularan COVID-19. 2020, 1-24.

Mona, N. (2020). Konsep Isolasi Dalam Jaringan Sosial Untuk Meminimalisasi Efek Contagious (Kasus Penyebaran Virus Corona Di Indonesia). Jurnal Sosial Humaniora Terapan, 2(2),117-125.https://doi.org/10.7454/jsht.v2i2.86

Moudy, J., \& Syakurah, R. A. (2020). Pengetahuan terkait usaha pencegahan Coronavirus Disease (COVID-19) di Indonesia. Higeia Journal of Public Health Research and Development, 4(3), 333-346. https://doi.org/10.15294/higeia.v4i3. 37844

Murhadi, T., \& Kurniawati, E. (2019). The Effect of Self Efication Factors on Teenager. Journal of Healthcare Technology and Medicine, 5(2), 239-246. https://doi.org/10.33143/jhtm.v5i2. 440
Novita, N. W., \& Yuliastuti, C. (2014). Tingkat Pengetahuan Tentang TB Paru Mempengaruhi Penggunaan Masker Di Ruang Paru Rumkital Dr. Ramelan Surabaya. Jurnal Ilmiah Kesehatan, 7(1), 46-61. https://doi.org/https://doi.org/10.33086/jhs.v7i1. 486

Parwanto, E. (2021). Virus Corona (SARS-CoV-2) penyebab COVID-19 kini telah bermutasi. Jurnal Biomedika Dan Kesehatan, 4(2), 4749.https://doi.org/10.18051/jbiomedkes.2021.v $4.47-49$

Peng, Y., Pei, C., Zheng, Y., Wang, J., Zhang, K., Zheng, Z., \& Zhu, P. (2020). Knowledge, Attitude and Practice Associated with COVID19 among University Students: a CrossSectional Survey in China. BMC Public Health, 20(1292), 1-8. https://doi.org/10.21203/rs.3.rs$21185 / \mathrm{v} 1$

Purnamasari, I., \& Raharyani, A. E. (2020). Tingkat Pengetahuan Dan Perilaku Masyarakat Kabupaten Wonosobo Tentang Covid -19. Living Islam: Journal of Islamic Discourses, 3(1), 125. https://ojs.unsiq.ac.id/index.php/jik/article/view/ $1311 / 783$

Rustika, I. M. (2016). Efikasi Diri: Tinjauan Teori Albert Studi, Program Fakultas, Psikologi Universitas, Kedokteran. Buletin Psikologi, 20(1-2), 18-25. https://doi.org/10.22146/bpsi.11945

Safitri, D. P., \& Masykur, A. M. (2017). Hubungan Efikasi Diri Dengan Kecemasan Menghadapi Kejuaraan Nasionalpada Atlet Tenis Lapangan Pelti Semarang. Empati, 6(2), 98-105. https://ejournal3.undip.ac.id/index.php/empati/a rticle/view/19736

Salman, M., Mustafa, Z. U., Asif, N., Zaidi, H. A., Hussain, K., Shehzadi, N., Khan, T. M., \& Saleem, Z. (2020). Knowledge, attitude and preventive practices related to COVID-19: a cross-sectional study in two Pakistani university populations. Drugs and Therapy Perspectives, 36(7), 319-325. https://doi.org/10.1007/s40267-020-00737-7 
Setyaningrum, A. P. (2019). Hubungan Tingkat Pengetahuan Dan Efikasi Diri Hubungan Tingkat Pengetahuan Dan Efikasi Dengan Perilaku Periksa Payudara Sendiri Diri Dengan Perilaku Periksa Payudara (Sadari) Pada Mahasiswa Ilmu Keperawatan Sendiri (Sadari) Pada Mahasiswa Ilmu Keperawatan. In Universitas 'Aisyiyah Yogyakarta.

Shofiah, V., \& Raudatussalamah. (2014). SelfEfficacy dan Self- Regulation Sebagai Unsur Penting dalam Pendidikan Karakter. Kutubkhanah: Jurnal Penelitian Sosial Keagamaan, 17(2), 214-229. http://ejournal.uinsuska.ac.id/index.php/Kutubkhanah/article/v iew/818

Silalahi, C., Lampus, B. S., \& Akili, R. (2013). Hubungan antara pengetahuan dan sikap perawat tentang HIV / AIDS dengan tindakan perawat terhadap penderita HIV / AIDS di Rumah Sakit Pancaran Kasih Manado. Media Kesehatan FKM UNSRAT, 46, 1-5. https://fkm.unsrat.ac.id/wpcontent/uploads/2013/08/JURNAL-

CHRISTINE-SILALAHI-09.pdf

Siltrakool, B. (2017). Assessment of Community Pharmacists 'Knowledge, Attitude and Practice Regarding Non-Prescription Antimicrobial Use and Resistance in Thailand BUDH SILTRAKOOL Submitted to the University of Hertfordshire in partial fulfilment of the requirements for the. October.

Susanti, R., \& Sri, N. (2020). Hubungan Pengetahuan Mahasiswa Dengan Perilaku Pencegahan Penyebaran Virus COVID-19. PROMOTIF: Jurnal Kesehatan Masyarakat, 10(2), 160-166. https://doi.org/10.31934/pjkm.v10i2.1123

Susilo, A., Rumende, C. M., Pitoyo, C. W., Santoso, W. D., Yulianti, M., Sinto, R., Singh, G., Nainggolan, L., Nelwan, E. J., Khie, L., Widhani, A., Wijaya, E., Wicaksana, B., Maksum, M., Annisa, F., Jasirwan, O. M., \& Yunihastuti, E. (2020). Coronavirus Disease 2019: Tinjauan Literatur Terkini Coronavirus Disease 2019: Review of Current Literatures. Jurnal Penyakit Dalam Indonesia, 7(1), 45-67. https://doi.org/10.7454/jpdi.v7i1.415
Taye, G. M., Bose, L., Beressa, T. B., Tefera, G. M., Mosisa, B., Dinsa, H., Birhanu, A., \& Umeta, G. (2020). COVID-19 knowledge, attitudes, and prevention practices among people with hypertension and diabetes mellitus attending public health facilities in Ambo, Ethiopia. Infection and Drug Resistance.https://doi.org/10.2147/IDR.S283 999

Timah, S. (2021). Hubungan Penyuluhan kesehatan dengan Pencegahan covid 19 di Kelurahan kleak kecamatan Malalayang Kota Manado. Indonesian Journal of Community Dedication, 3(1), 7-14.

Wadood, A., Mamun, A., \& Rafi, A. (2020). Knowledge, attitude, practice and perception regarding COVID-19 among students in 2 Bangladesh: Survey in Rajshahi University. $B M J$

Yale. https://doi.org/10.1101/2020.04.21.2007475 7

Yulianti, T. (2021). Pengetahuan Dan Sikap Berhubungan Dengan Perilaku Pencegahan COVID-19 Pada Keluarga Usia Lanjut Di Wilayah Kecamatan Sukaharjo. Indonesian Journal On Medical Science, 8 No.1(1), 915.https://ejournal.ijmsbm.org/index.php/ijm s/article/view/251

Yunus, N. R., \& Rezki, A. (2020). Kebijakan Pemberlakuan Lock Down Sebagai Antisipasi Penyebaran Corona Virus COVID-19. SALAM: Jurnal Sosial Dan Budaya Syar-I. https://doi.org/10.15408/sjsbs.v7i3.15083

Zhong, B. L., Luo, W., Li, H. M., Zhang, Q. Q., Liu, X. G., Li, W. T., \& Li, Y. (2020). Knowledge, attitudes, and practices towards COVID-19 among chinese residents during the rapid rise period of the COVID-19 outbreak: A quick online cross-sectional survey. International Journal of Biological Sciences, 16(10), 1745-1752. https://doi.org/10.7150/ijbs.45221

Zulva, T. N. I. (2020). COVID-19 Dan Kecenderungan Psikosomatis. Journal of Chemical Information and Modeling, 1-4. https://doi.org/10.1017/CBO9781107415324 .004 